\title{
NYITOTT CELLÁS FÉMHABOK GEOMETRIAI MODELLEZÉSÉNEK MÓDSZEREI
}

\section{METHODS FOR GEOMETRIC MODELING OF OPEN CELL METAL FOAMS}

\author{
Sándor Roland ${ }^{1 *}$ \\ ${ }^{1}$ Jármütechnológia Tanszék, GAMF Müszaki és Informatikai Kar, Neumann János Egyetem, Magyarország \\ https://doi.org/10.47833/2020.2.ENG.004
}

\section{Kulcsszavak: \\ vizuális programozás \\ fémhabok \\ geometriai modell alkotás}

\section{Keywords:}

visual programming

metal foam

geometric model makeing

\section{Cikktörténet:}

Beérkezett 2020. június 10.

Átdolgozva 2020. június 20.

Elfogadva 2020. július 1.

\begin{abstract}
Összefoglalás
A fémhabok gyakorlati alkalmazása számos problémát vet fel. Sok ezek közül a habszerkezet kiszámithatatlanságából ered. Ezen problémákra megoldást jelenthet a fémhab struktúrák digitális, végeselemes szimulációs térben történő vizsgálata. Az ilyen szimulációk első lépése a vizsgálandó tárgy geometriai modelljének elkészitése. A cikk egy lehetséges módszert tár fel, nyitott cellás fémhabok geometriai modelljének elkészítésére, a vizuális programozás eszközeivel. Ezen módszer alkalmazásával lehetővé válik tetszőleges formai jellemzőkkel bíró fémhab struktúra geometriai modelljének elkészítése, mely felhasználható végeselemes szimulációk során.
\end{abstract}

\begin{abstract}
The practical application of metal foams cause many problems. Many of these results from the unpredictability of the foam structure. These problems can be solved by examining the metal foam structures in a digital finite element simulation space. The first step in such simulations is to construct a geometric model of the object under investigation. This article explores a possible method for creating a geometric model of open cellular foams using visual programming tools. By using this method, it is possible to create a geometric model of a metal foam structure of any shape, which can be used in finite element simulations.
\end{abstract}

\section{Bevezetés}

A jármüipar és a repülögépipar területein mindíg is nagy hangsúlyt fektettek a gépipari konstrukciók tömegének csökkentésére. A gyártási technológiák és az anyagtudomány fejlődésével a közelmúltban is új lehetőségek nyíltak ezen cél korszerű megvalósítására. Ezen újítások egyike a fémhabokban mutatkozik, melyek olyan gépelemek alapanyagául szolgálhatnak, melyek elsősorban statikus igénybevételnek vannak kitéve, de remek energiaelnyelő képességük révén gyürődő biztonsági elemekként is hasznosíthatók. Nehézséget jelent azonban, hogy a habok szerkezetét, gyártási technológiájukból adódóan relatíve nagy bizonytalanság jellemzi. A habszerkezet celláinak eloszlása egy adott tartományon belül változik így terhelés hatására minden legyártott alkatrész másképpen viselkedik. Erre a problémára megoldást jelenthet a fémhab szerkezetek végeselemes szimulációk útján történő vizsgálata. Ennek első lépése azonban a vizsgálandó test geometriai

\footnotetext{
* Kapcsolattartó szerző: E-mail: sandor.roland@gamf.uni-neumann.hu
} 
modelljének elkészítése. Habszerkezetröl lévén szó, a szóban forgó geometriai struktúra meglehetősen bonyolult. Hagyományos CAD modellezési technikákkal nem előállítható. [1] Ahogyan az, egy 2016-ban a Debreceni Egyetem kutatói által írt cikkben is olvasható a fémhabok geometriai modelljének előállítására két lehetséges módszer ismert. Az első módszer során egy legyártott hab struktúrájú alkatrészt CT vizsgálat segítségével elemzünk és az így kapott keresztmetszeti képekből állítjuk elő a geometriai modelt. A módszer előnye, hogy nagyon pontos képet kapunk a szerkezet felépítéséröl, hátránya azonban, hogy egy adott hab szerkezet modellje állítható elő így, tehát az így kapott geometriai modell csak a vizsgált struktúrát jellemzi. A második módszer hogy a habstruktúra felépítésének tanulmányozását követően valamilyen algoritmus segítségével állítjuk elő a geometriai modelt. Ennek hátránya, hogy kevésbé pontos eredményt kapunk. Előnye azonban hogy sokkal gyorsabb az elsőként ismertetett módszernél és hogy, a geometriai modelleket a bemeneti paraméterek megváltoztatásával könnyen módosíthatjuk. Ezáltal rövid idő alatt kevés energia befektetéssel rengeteg különböző geometriai modelt kapunk, melyek elfogadható pontossággal tükrözik a valóságot. Jelen cikk célja, egy lehetséges megoldás bemutatása a másodikként tárgyalt módszer megvalósítására.

\section{Fémhabok szerkezete}
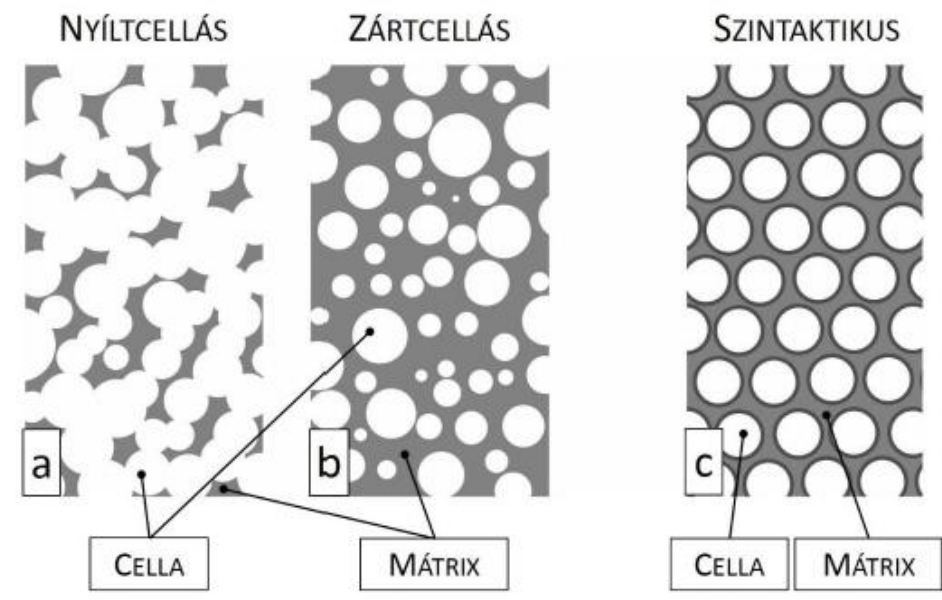

1) ábra [2] A hab anyagok csoportositása a belső struktúra alapján

[2] "Habok alatt olyan cellás szerkezetű anyagokat értünk, ahol egy befoglaló anyagban (mátrix) légnemű részek (cellák) találhatóak. Ezeket az anyagokat két nagy csoportba sorolhatjuk a belső szerkezet függvényében: nyílt- (1.a ábra), illetve zártcellás (1.b ábra) habok csoportjára. Nyílt cellás habokról akkor beszélhetünk, ha az anyagban megtalálható cellákat nem választja el egymástól cellafal, azok között az átjárás megvalósítható. A természetben megtalálható szerves cellás anyagok (pl. csont, korall) tipikusan ebbe a kategóriába tartoznak. A zártcellás habok esetében, ahogy neve is jelzi, az anyagban a cellák egymástól elhatároltak, a határokat a cellafalak jelentik. Ennek okán az egyes cellák között nincs átjárásra lehetőség." Geometriai modellezésröl csakis nyitott cellás habok esetén beszélhetünk, mivel a digitális 3D modellező szoftverek minden zárt üreget tömör testként értelmeznek. Ennek megfelelően a későbbiekben ismertetett algoritmus nyitott cellás struktúrát hoz létre.

\section{A vizuális programozás módszereinek alkalmazása a modellalkotásban}

A vizuális programozás eszközei lehetővé teszik, hogy a felhasználó egy szoftver alapeszközeit tetszőleges módon kombinálva saját algoritmusokat készítsen programozói háttérismeret nélkül. A hab struktúra geometriai modelljét létrehozó algoritmus elkészítése a Rhinoceros 3D nevű szoftver Grasshopper névre hallgató moduljában történt. Az említett modul lehetővé teszi, hogy a felhasználó az alapszoftver eszközeit elérje funkció blokkok formájában (2. ábra). Minden funkcióblokknak vannak kimenetei és bemenetei. A funkció blokkok ki és bemeneteit vonalakkal köthetjük össze ezzel adva meg a blokkok közötti kapcsolat jellegét. Az elérhető blokkok 
között vannak, amelyek egészen egyszerü müveleteket végeznek, például összeadják a bemenetekre kötött szám jellegű változókat, és vannak egészen bonyolultak is melyek iterációs számítást végeznek egy célparaméter elérése érdekében. Ez a blokkdiagrammos felépítés lehetővé teszi paraméteres modellek elkészítését bonyolult, organikus formák esetén is.

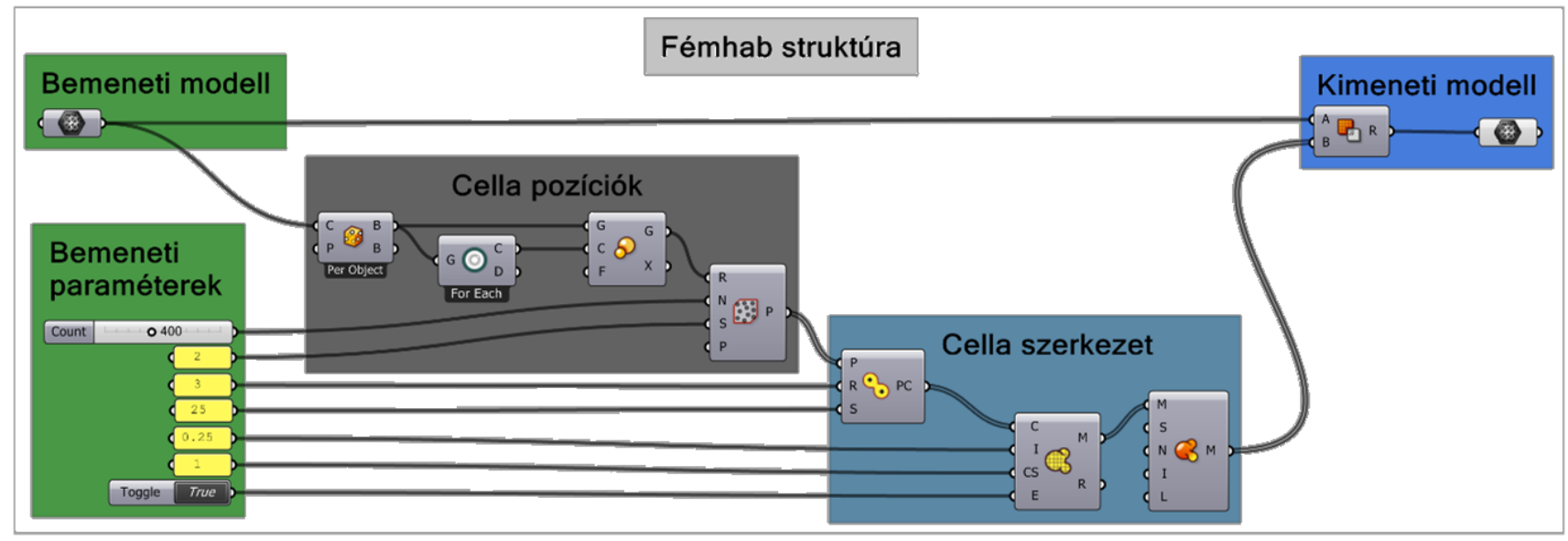

2) ábra A hab szerkezet geometriai modelljét létrehozó algoritmus blokkdiagrammos ábrázolása

\section{A geometriai modell alkotás folyamata}

a)

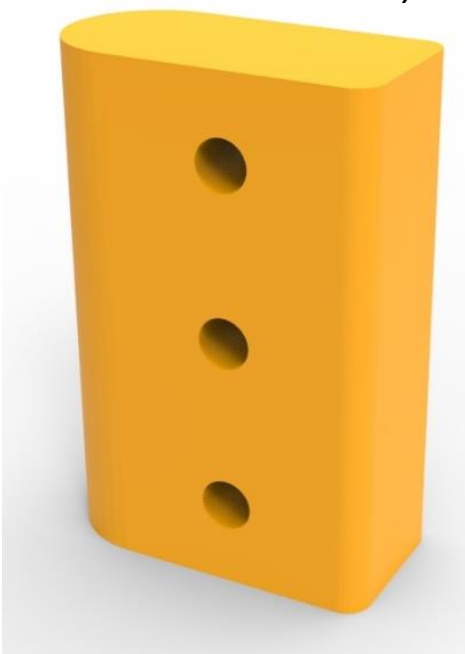

b)

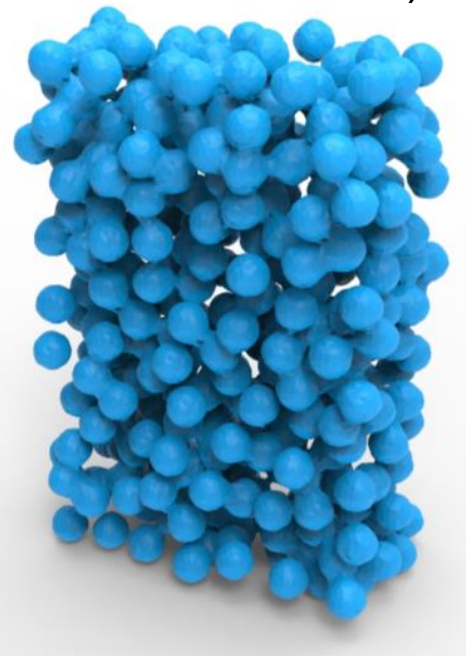

c)

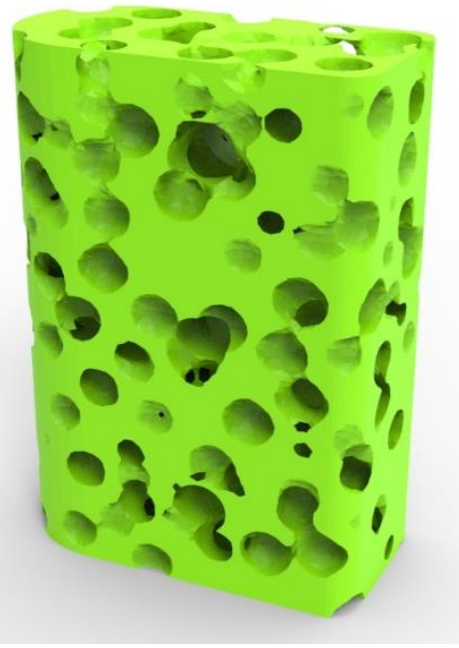

3) ábra A geometriai modell alkotás lépései

A geometriai modell alkotás során az algoritmus megnyitja a CAD szoftverben elkészített modelt mely tetszőleges alaksajátosságokkal rendelkezik (3a ábra). Ezt követően meghatározza azt a téglatestet, amelybe a megnyitott modell pontosan illeszkedik. Ebben a téglatest formájú tartományban általunk meghatározott számú véletlenszerủ helyzetű pontot határoz meg. A megadott pontszám a habszerkezetünk celláinak számát fogja meghatározni. Az algoritmus rugalmasságának köszönhetően megoldható hogy ne a teljes tartományra eső pontok számát kelljen megadnia a felhasználónak, hanem az egységnyi térfogatra eső pontok számát. Igy elérhető, hogy külön beavatkozás nélkül, változó geometriájú és térfogatú modellekböl közel azonos sürűségü hab szerkezetet idéző modelleket hozzon létre az algoritmus.

Ezt követően a meghatározott véletlenszerü pontokra háromszög ráccsal burkolt gömböket helyez, melyek átméröit szintén mi határozzuk meg. Fontos megjegyezni, hogy a gömböket burkoló háromszög rácsok felbontását is módunkban áll módosítani. Nagyobb felbontásnál az algoritmus több háromszöggel burkolja a gömböt, így a modell egyre kevésbé less szögletes és egyre jobban 
hasonlít a valóságos fémhabokhoz. Ennek azonban az az ára, hogy a modelt alkotó poligonok száma drasztikusan megnő és így a modellalkotáshoz szükséges számítások teljesítmény igénye is jelentősen megnő. A gömbök átmérői véletlenszerüen változnak egy általunk megadott tartományon belül. Célszerü ebben a lépésben nem túl nagy tartományt megadni, mivel a nagymértékben eltérő átmérőjü gömbök későbbi feldolgozása lényegesen nehezebb az algoritmus számára. Ez a modellben jelentkező geometriai hibákhoz és a modellalkotáshoz szükséges teljesítmény igény megnövekedéséhez vezet.

Lehetőség van egy olyan paraméter meghatározására is mely meghatározza azt a legkisebb távolságot, amin belül a gömböket az algoritmus egyesíti. Az így kapott organikus alaksajátosság testesíti meg a cellák formáját ( $3 b$ ábra).A gömbök egyesítése akkor a leg eredményesebb, ha a megadott távolság nagyobb, mint a gömbök középpontját meghatározó pontfelhő, egymáshoz legközelebb lévő pontjainak átlagos távolsága. Ha a megadott távolság túl kicsi, akkor a gömbök nem egyesülnek kellő mértékben és az utolsó lépésben a cellákat megtestesíteni hivatott modellt , az algoritmus nem fogja tudni kivonni a betöltött CAD modell geometriájából. Ha túl nagy távolságot adunk meg akkor nagy méretű cellák jönnek létre és a modell nem fogja megfelelő pontossággal tükrözni a valóságot.

A végleges geometriai modelt a két elözőekben ismertetett test különbségeként határozza meg az algoritmus ( $3 c$ ábra). Az így kapott modell jól közelít a nyitott cellás fémhabok geometriai jellemzőire. Lehetőség van a bemeneti paraméterek változtatásával befolyásolni a cellaméretet és a cellák számát egyaránt, ezzel a felhasznált számítógép teljesítményétöl függően akár szinte valós időben változtatva meg a habszerkezet sürüségét és jellegét.

\section{A modellek felhasználásának lehetőségei}

Az algoritmus lefutása után egy háromszögekböl álló, úgynevezett „mesh” modelt kapunk. Ebben a formátumban végeselemes analízis lefuttatására alkalmas szoftverekben történő felhasználásra még nem alkalmas a modell. Ahhoz hogy fel tudjuk használni az elkészített modellt a „mesh” modelt tömör test modellé kell alakítanunk. Ennek módja, hogy a modelt alkotó háromszögeket úgy nevezett „NURBS” felületekké alakítjuk egy erre a célra alkalmas funkcióblokkal a vizuális programozást lehetővé tevő felületen belül. Az így kapott felület modelt pedig szilárd test modellé alakítás parancs segítségével olyan formába tudjuk hozni, mely alkalmas a későbbiekben arra, hogy a végeselemes analízis során a szoftver el tudja végezni a szükséges térhálósítást.

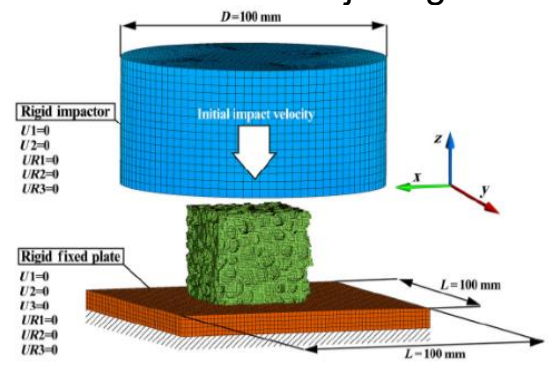

4) ábra [3] Fémhab modell végeselemes vizsgálata

\section{Köszönetnyilvánítás}

A projekt az Európai Unió támogatásával, az Európai Szociális Alap társfinanszírozásával valósul meg. EFOP-3.6.1-16-2016-00014

The project has been supported by the European Union, co-financed by the European Social Fund. EFOP3.6.1-16-2016-00014.

\section{Irodalomjegyzék}

[1] "Fémhabstruktúrák elemzése és geometriai modellezése" Varga Tamás; Mankovits Tamás. 2016 International Journal of Engineering and Management Sciences (IJEMS) Vol. 1. (2016). No.2. DOI: 10.21791/IJEMS.2016.2.19.

[2] „Szintaktikus fémhabok mechanikai tulajdonságai ciklikus, illetve nagy alakváltozási sebességű zömítés során PhDértekezés" Katona Bálint. 2018 pp 11. 
[3] „Numerical and experimental analysis of the closed-cell aluminium foam under low velocity impact using computerized tomography technique." S. Talebi, M. Sadighi, M. M. Aghdam. Acta Mechanica Sinica, 35,(1): 144155(2018) Doi:10.1007/s10409-018-0795-7 